\title{
PENINGKATAN AKTIVITAS DAN HASIL BELAJAR IPS MELALUI MODEL PEMBELAJARAN PICTURE AND PICTURE PADA SISWA KELAS 2
}

\author{
Mega Wahyuningsih \\ Sekolah Dasar Negeri Medani 02, Cluwak Kabupaten Pati \\ mega.wahyuningsih900@gmail.com
}

Page $\mid 73$

\begin{abstract}
Abstrak
Model pembelajaran picture and picture merupakan model pembelajaran yang dapat membantu pembelajaran IPS. Guru menggunakan alat bantu seperti media gambar untuk menerangkan sebuah materi atau memfasilitasi siswa untuk aktif belajar yang bertujuan untuk meningkatkan aktivitas dan hasil belajar siswa kelas II SD Negeri Medani 02 Kecamatan Cluwak Kabupaten Pati. Adapun manfaat yang biasa didapatkan diantaranya menambah ilmu pengetahuan dan memperluas wawasan bagi peneliti khususnya dan bagi para pendidik umumnya mengenai model pembelajaran dan media pembelajaran yang menarik sehingga lebih meningkatkan minat belajar siswa. Penelitian ini yang menjadi subjek penelitian adalah guru dan siswa kelas II SD Negeri Medani 02 Kecamatan Cluwak Kabupaten Pati sebanyak 1 guru dan 12 siswa yang terdiri dari 6 siswa laki-laki dan 6 siswa perempuan. Sumber data dari penelitian ini berasal dari guru, siswa, data dokumen dan catatan lapangan. Hasil pelaksanaan penelitian siklus I menunjukkan peningkatan. Rata-rata hasil belajar siswa menjadi 71,42 dengan nilai terendah 50 dan nilai tertinggi 90 . Sebanyak 4 siswa belum memenuhi KKM dan 10 siswa telah mencapai KKM. Persentase ketuntasan siswa sebesar $71,42 \%$ siswa yang tuntas dan $28,58 \%$ siswa yang belum tuntas. Pada penelitian siklus II menunjukkan peningkatan rata-rata hasil belajar siswa menjadi 88,57 dengan nilai terendah 70 dan nlai tertinggi 100. Semua siswa telah mencapai KKM. Persentase ketuntasan siswa sebesar $100 \%$ siswa yang tuntas. Dari hasil tersebut dapat diambil kesimpulan bahwa indikator keberhasilan yang telah ditetapkan telah tercapai.
\end{abstract}

Kata kunci: Model pembelajaran picture and picture, IPS, hasil belajar 
completeness is $100 \%$. From these results it can be concluded that the predetermined success indicators have been achieved.

Keywords: Picture and picture learning model, Social studies, learning outcomes.

\section{A. Pendahuluan}

Menurut Permendiknas RI No. 22 Tahun 2006 tentang Standar Isi mata pelajaran IPS SD/MI, memuat bahwa Ilmu Pengetahuan Sosial (IPS) merupakan salah satu mata pelajaran yang diberikan mulai dari SD/MI/SDLB sampai SMP/MTs/SMPLB, dimana IPS dalam pembelajaran mengkaji seperangkat peristiwa, fakta, konsep, dan generalisasi yang berkaitan dengan isu sosial. ${ }^{1}$ Pada jenjang SD/MI, mata pelajaran IPS memuat materi geografi, sejarah, sosiologi, dan ekonomi. Pendidikan nasional khususnya dalam mata pelajaran IPS bertujuan untuk berkembangnya potensi peserta didik agar menjadi manusia yang beriman dan bertaqwa kepada Tuhan Yang Maha Esa, berakhlak mulia, berilmu, cakap, kreatif, mandiri dan menjadi warga negara yang demokratis. ${ }^{2}$

Sesuai dengan Peraturan Menteri Pendidikan Nasional no 22 Tahun 2006, tujuan pembelajaran IPS di tingkat SD adalah sebagai berikut: (1) Mengenal konsep-konsep yang berkaitan dengan kehidupan masyarakat dan lingkungannya, (2) Memiliki kemampuan dasar untuk berpikir logis dan kritis, rasa ingin tahu, inkuiri, memecahkan masalah, dan keterampilan dalam kehidupan sosial, (3) Memiliki komitmen dan kesadaran terhadap nilai-nilai sosial dan kemanusiaan, (4) Memiliki kemampuan berkomunikasi, bekerjasama dan berkompetisi dalam masyarakat yang majemuk di tingkat lokal, nasional dan global. ${ }^{3}$ Ruang lingkup mata pelajaran IPS menurut Standar Isi (2007) meliputi aspek-aspek sebagai berikut : (1) Manusia, Tempat dan Lingkungan, (2) Waktu, Keberlanjutan dan Perubahan, (3) Sistem Sosial dan Budaya, dan (4) Perilaku Ekonomi dan Kesejahteraan. ${ }^{4}$

Melalui mata pelajaran IPS, peserta didik diarahkan untuk dapat menjadi warga negara Indonesia yang demokratis, dan bertanggung jawab, serta warga dunia yang cinta damai. Di masa yang akan datang peserta didik akan menghadapi tantangan berat karena kehidupan masyarakat global selalu mengalami perubahan setiap saat. Oleh karena itu mata pelajaran IPS dirancang untuk mengembangkan pengetahuan,

\footnotetext{
${ }^{1}$ Kurikulum Tingkat Satuan Pendidikan.Jakarta:Depdiknas 2006, pasal 2

${ }^{2}$ Anton, M.Aktivitas Belajar. Bandung:Alfabet, hlm. 31

${ }^{3}$ Peraturan Menteri Pendidikan Nasional No.22 tahun 2006, pasal 2

${ }^{4}$ Peraturan Menteri Pendidikan Nasional Republik Indonesia Nomor 41 Tahun 2007 tentang Standar Proses
} 
pemahaman, dan kemampuan analisis terhadap kondisi sosial masyarakat dalam memasuki kehidupan bermasyarakat yang dinamis. Mata pelajaran IPS disusun secara sistematis, komprehensif, dan terpadu dalam proses pembelajaran menuju kedewasaan dan keberhasilan dalam kehidupan di masyarakat. Pembelajaran IPS tentu tidak hanya menuntut siswa memahami materi saja tetapi mampu membawa keberhasilan dalam kehidupan bermasyarakat. ${ }^{5}$

Dengan metode tersebut yang digunakan oleh guru untuk mewujudkan suasana belajar dan proses pembelajaran agar peserta didik mencapai kompetensi dasar atau seperangkat indikator yang telah ditetapkan. ${ }^{6}$ Berdasarkan refleksi awal yang telah dilakukan bahwa pembelajaran IPS masih belum optimal. Hal itu dikarenakan guru dalam melakukan pembelajaran belum menggunakan model pembelajaran bervariasi, guru masih sering menggunakan metode ceramah sehingga siswa kurang aktif, cepat merasa bosan. Oleh karena itu guru mencoba menggunakan model pembeljaran picture and picture. Model pembelajaran picture and picture merupakan model pembelajaran yang dapat membantu pembelajaran IPS materi IPS dokumen keluarga sebagai sumber belajar $^{7}$

Alasan masalah ini penting untuk segera dicari pemecahannya karena sebanyak 64,28\% (9 dari 12) siswa di kelas II SD Negeri Medani 02 Kecamatan Cluwak kesulitan dalam pelajaran IPS. Oleh karena itu mata pelajaran IPS dirancang untuk mengembangkan pengetahuan, pemahaman, dan kemampuan analisis terhadap kondisi sosial masyarakat dalam memasuki kehidupan bermasyarakat yang dinamis. Pendidikan IPS sangat penting diberikan kepada siswa pada jenjang pendidikan dasar karena siswa yang datang ke sekolah berasal dari lingkungan yang berbeda-beda. Siswa sebagai anggota masyarakat perlu mengenal masyarakat dan lingkungannya. Untuk mengenal masyarakat, siswa dapat belajar mulai dari media cetak, elektronik maupun langsung dari pengalaman hidupnya di tengah-tengah masyarakat. ${ }^{8}$

${ }^{5}$ Fitria Martanti, Penanaman Konsep Gender Pada Mata Pelajaran IPS, Jurnal Magistra Volume 8 Nomer 1 2017, hlm. 80

${ }^{6}$ Peraturan Menteri Pendidikan Nasional Republik Indonesia Nomor 41 Tahun 2007 tentang Standar Proses, Pasal 1

${ }^{7}$ Dewi Diansari, Penerapan Model Picture and Picture untuk Meningkatkan Pembelajaran IPA Siswa Kelas I SDN Gampingan 01 Pagak. Skripsi. 2011.

8 Thursan . Belajar. Jakarta: Bumi Aksara, 2000. hlm 44 


\section{B. Metode Penelitian}

Metode penelitian yang diambil peneliti adalah penelitian PTK. Karena dengan Penelitian Tindakan Kelas dapat memperbaiki praktek pembelajaran dengan sasaran akhir memperbaiki belajar siswa. ${ }^{9}$ Pada dasarnya penelitian tindakan diperlukan untuk mencermati dan memperbaiki sisi yang menjadi kekurangan dari sesuatu yang diteliti tersebut. ${ }^{10}$ Dengan PTK kesalahan dalam proses pembelajaran akan cepat dianalisis dan diperbaiki, sehingga kesalahan tersebut tidak akan berlanjut. ${ }^{11}$ Penelitian tindakan kelas ini dilakukan di kelas II SD Negeri Medani 02 Kecamatan Cluwak Kabupaten Pati yang berada di tengah-tengah kota kecamatan. Keadaan masyarakat lingkungan masih kental suasana pedesaan sedangkan yang berhubungan dengan gedungnya cukup baik. Sarana pembelajaran juga baik, begitu juga media pembelajaran mata pelajaran IPS. Sekolah ini memiliki 8 ruang kelas, 1 ruang kepala sekolah merangkap ruang tamu, 1 ruang guru, 1 ruang UKS, 2 kamar mandi siswa, 2 kamar mandi guru dan karyawan. Adapun yang menjadi subjek penelitian adalah siswa kelas II dengan jumlah 12 siswa terdiri dari 12 siswa putra 6 dan 6 siswa putri.

Adapun alasan pemilihan sekolah ini sebagai lokasi penelitian yaitu: Pertama, berdasarkan hasil obserasi awal guru kelas dalam mengajar mata pelajaran IPS ditemukan adanya kendala dalam materi dokumen keluarga sebagai sumber belajar. Kedua sekolah tersebut belum pernah digunakan sebagai penelitian yang sejenis, sehingga terhindar dari kemungkinan penelitian ulang.

Subjek penelitian tindakan kelas ini adalah siswa kelas II SD Negeri Medani 02 dengan jumlah murid 12 siswa, yang terdiri dari 6 anak perempuan dan 6 anak laki-laki. Karena latar belakang siswa yang hidup di pedesaan dan kampung persawahan, maka minat belajar siswa kurang, kondisi ini di tambah dengan orang tua siswa yang kurang begitu memperhatikan anaknya dalam belajar, karena orang tua pada umumya bekerja di perantauan, buruh dan petani. Sebagian orang tua siswa berpendapat pendidikan bukanlah jaminan hidup bagi anaknya. Pendidikan tanpa modal sulit mencari pekerjaan. Jumlah siswa kelas II yaitu 12 siswa yang terdiri dari 6 siswa laki-laki dan 6 siswa perempuan mempunyai pribadi atau karakter siswa yang tidak sama ada anak yang nakal tidak mau memperhatikan penjelasan guru, bicara sendiri bahkan ada yang

9 Suharsimi Arikunto, dkk. Penelitian Tindakan Kelas. Jakarta: PT Bumi Aksara, 2010. hlm 9

${ }^{10}$ Fitria Martanti, Penanaman Nilai-nilai Kejujuran Melalui Media Kantin Kejujuran di Pondok Pesantren Al-Hikmah Semarang, Jurnal Sosio Dialektika Volume 2, 2017. hlm. 49

${ }^{11}$ Suharsimi Arikunto, dkk. Penelitian Tindakan Kelas. Jakarta: PT Bumi Aksara, 2010. hlm 62 
bermain di kelas. Sebagai guru tentu harus mengubah sifat pribadi siswa yang demikian, Selain nakal ada juga anak yang merasa minder atau takut terhadap guru, sehingga anak itu tidak pernah mengemukakan pendapat karena takut salah. Dengan perbedaan pribadi siswa yang demikian ini mempengaruhi juga hasil belajar. Sebagian anak yang nakal dan takut, mendapatkan nilai yang kurang memuaskan.

\section{Hasil dan Pembahasan}

Kedudukan dan fungsi guru cenderung lebih dominan dibandingkan aktivitas siswa. Permasalahan tersebut juga dialami oleh guru SDN Medani 02 Kecamatan Cluwak Kabupaten Pati, khususnya guru kelas II ketika melaksanakan pembelajaran IPS. Berdasarkan refleksi awal yang telah dilakukan bahwa pembelajaran IPS masih belum optimal. Hal itu dikarenakan guru dalam melakukan pembelajaran belum menggunakan model pembelajaran bervariasi, guru masih sering menggunakan metode ceramah sehingga siswa kurang aktif, cepat merasa bosan sehingga mempengaruhi belajar siswa, dan adanya media kurang memadai. Keterlibatan siswa dalam pembelajaran masih rendah, siswa cenderung pasif dan lebih banyak mendengarkan penjelasan dari guru. Saat guru menjelaskan materi pelajaran, banyak siswa yang kurang memperhatikan. Keaktifan atau motivasi belajar siswa yang rendah berpengaruh terhadap rendahnya hasil belajar, sehingga indikator keberhasilan belum tercapai sesuai dengan KKM yaitu (65). Hasil tes kondisi awal dapat dilihat pada lembar lampiran. Dari hasil tes kondisi awal dapat diketahui jumlah siswa yang tuntas dan yang tidak tuntas, nilai minimum, nilai maksimum, dan nilai rata-rata kelas. Berikut kategori ketuntasan belajar siswa pada mata pelajaran IPS pada kondisi awal:

Tabel 1

Kategori Frekuensi Prosentase

\begin{tabular}{|l|c|c|}
\hline Kategori & Frekuensi & Prosentase \\
\hline Tuntas & 5 & $42,85 \%$ \\
\hline Tidak Tuntas & 7 & $57,15 \%$ \\
\hline Rata-rata & - & 58,57 \\
\hline Jumlah Siswa & 12 & $100 \%$ \\
\hline
\end{tabular}

Tabel 1 dapat dilihat jumlah siswa yang tuntas dan tidak tuntas dari siswa yang berjumlah 12. Jumlah siswa yang tuntas adalah 5 anak dengan persentase $42,85 \%$. Sedangkan siswa yang tidak tuntas adalah 7 anak dengan persentase 57,15\%. Deskripsi 
kondisi awal, dapat diketahui bahwa separuh lebih dari jumlah siswa tidak tuntas. Untuk memperjelas Tabel 1 dapat dilihat pada diagram batang 1

\section{Hasil Belajar Kondisi Awal}

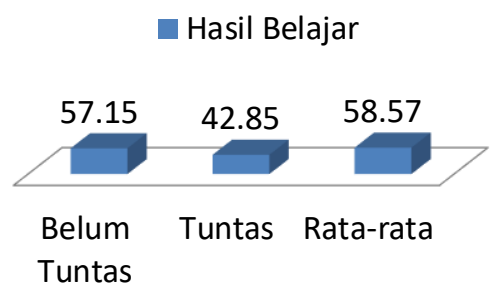

Selain dapat melihat jumlah dan persentase siswa yang mencapai tuntas sesuai dengan indikator kinerja yang diharapkan, yaitu $80 \%$ siswa memperoleh nilai $\geq 65$. Proses pembelajaran difokuskan pada permasalahan yang ada pada pembelajaran sebelumnya yuaitu sebelum penerapan model pembelajaran Picture and Picture. Pada saat ini peneliti menyusun strategi pembelajaran yang sesuai agar hasil belajar siswa dapat meningkat.

1. Perencanaan Tindakan

Perbaikan pembelajaran siklus I dilakukan melalui penerapan model pembelajaran Picture and Picture pada materi IPS dokumen keluarga sebagai sumber belajar. Persiapan yang dilakukan penulis untuk melaksanakan siklus I sebagai berikut. 12 :

a. Menyusun RPP dengan materi IPS dokumen keluarga sebagai sumber belajar

b. Mengajak tim kolaborasi atau guru kelas II sebagai rekan peneliti untuk berkolaborasi dalam penelitian

c. Mempersiapkan sumber dan media pembelajaran berupa gambar-gambar

d. Menyiapkan lembar observasi untuk mengamati aktivitas siswa, guru dan proses pembelajaran.

e. Menyiapkan alat evaluasi berupa tes tertulis dan lembar kerja siswa.

2. Pelaksanaan Tindakan

Siklus pertama dilaksanakan 2 kali pertemuan yaitu pada tanggal 10 dan 17 September 2020 bertempat di SD Negeri Medani 02 Kecamatan Cluwak Kabupaten Pati. Guru melaksanakan pembelajaran sesuai yang sudah direncanakan dalam Rencana

${ }^{12}$ Gie, Aktiitas Belajar, Jakarta: PT. Rineka Cipta, 2011, hlm 103 
Pelaksanaan Pembelajaran ${ }^{13}$. Urutan kegiatan yang dilaksanakan mulai dari kegiatan awal, kegiatan inti dan kegiatan akhir. ${ }^{14}$

Pelaksanaan tindakan diawali dari pertemuan pertama. Adapun pada pertemuan pertama kegiatan awal guru membuka pelajaran dengan mengabsen kehadiran siswa dan

memberikan motivasi dengan bercerita dan pada kegiatan inti dengan langkah-langkah guru melakukan apersepsi, membagi siswa menjadi 3 kelompok (tiap kelompok 4-5 siswa), menunjukkan gambar-gambar kegiatan berkaitan dengan materi, mengajak siswa berdiskusi dalam kelompoknya masing-masing mengenai gambar yang disajikan, siswa membentuk kelompok, di mana masing-masing kelompok menyusun gambar sesuai dengan materi yang diajarkan. Adapun Pada pertemuan kedua juga diawali dengan skenario yang sama dengan pertemuan pertama. Adapun dalam pelaksanaan siklus dapat dijelaskan sebagai berikut:

\section{Perencanaan}

Perbaikan pembelajaran siklus I dilakukan melalui penerapan model pembelajaran Picture and Picture pada materi IPS Dokumen Keluarga Sebagai Sumber Belajar. Persiapan yang dilakukan peneliti untuk melaksanakan siklus I adalah membuat RPP, mempersiapkan instrumen, alat dan bahan untuk penelitian agar tujuan pembelajaran dapat tercapai secara maksimal, RPP dan lembar obserasi dapat dilihat pada lampiran.

\section{Pelaksanaan Tindakan}

Pada kegiatan awal guru membuka pelajaran dengan mengabsen kehadiran siswa dan memberikan motiasi denganbercerita kemudian dilanjutkan dengan kegiatan inti Guru melakukan apersepsi, membagi siswa menjadi 3 kelompok (tiap kelompok 4-5 siswa), menunjukkan kepada siswa gambar-gambar kegiatan berkaitan dengan materi, mengajak siswa diskusi dalam kelompoknya masing-masing mengenai gambar yang disajikan, membentuk kelompok di mana masing-masing kelompok menyusun gambar sesuai dengan materi yang diajarkan, memberikan pertanyaan tentang alasan/dasar pemikiran urutan gambar tersebut dan menurut alasan/urutan gambar tersebut guru memulai menamkan konsep/materi dan memberikan pemantapan sesuai dengan kompetensi yang ingin dicapai.

\footnotetext{
${ }^{13}$ Djamarah, Syaifyk B, \&Zain, Aswan, Strategi Belajar Mengajar, Jakarta: Rineka Cipta. 2006

${ }^{14}$ Fisher Alec, Berfikir Kritis- Sebuah Pengantar. Jakarta. Erlangga, 2009. hlm 97
} 


\section{Observasi Siklus I}

Dari observasi yang dilakukan diperoleh hal-hal berikut pada tabel 2

Tabel 2

Hasil Observasi Guru Siklus I

\begin{tabular}{|c|c|c|c|c|c|c|}
\hline & \multirow{2}{*}{ Tahap } & \multirow{2}{*}{ Aspek yang diamati } & \multicolumn{4}{|c|}{ Skor penilaian } \\
\hline & & & 1 & 2 & 3 & 4 \\
\hline \multirow{26}{*}{ Page $\mid 80$} & I & Mengorientasi masalah & & & & \\
\hline & & 1. Menjelaskan tujuan pembelajaran & & & $\sqrt{ }$ & \\
\hline & & 2. Menyampaikan apersepsi & & & $\sqrt{ }$ & \\
\hline & & 3. Menarik perhatian dan minat belajar siswa & & & $\sqrt{ }$ & \\
\hline & & $\begin{array}{l}\text { 4. Memunculkan contoh-contoh masalah yang berkaitan dengan } \\
\text { kehidupan sehari-hari }\end{array}$ & & & & $\sqrt{ }$ \\
\hline & & $\begin{array}{l}\text { 5. Memotivasi siswa untuk menelaah soal dan menemukan cara } \\
\text { penyelesaiannya sendiri }\end{array}$ & & & $\sqrt{ }$ & \\
\hline & & $\begin{array}{l}\text { 6. Mengorganisasikan siswa untuk mengkonstruksi sendiri } \\
\text { pengetahuan yang didapatnya }\end{array}$ & & & $\sqrt{ }$ & \\
\hline & II & Membimbing kegiatan pembelajaran individual maupun kelompok & & & & \\
\hline & & 1. Melakukan pengamatan tiap kelompok & & & & $\sqrt{ }$ \\
\hline & & $\begin{array}{l}\text { 2.Mengawasi dan membimbing kegiatan kelompok dengan instruksi } \\
\text { seminimal mungkin }\end{array}$ & & & $\sqrt{ }$ & \\
\hline & & 3. Merekam kegiatan siswa & & & $\sqrt{ }$ & \\
\hline & III & Mengembangkan hasil kerja siswa & & & & \\
\hline & & $\begin{array}{l}\text { 1. Membimbing siswa dalam mengkonstruksi pengetahuan baru yang } \\
\text { didapat }\end{array}$ & & & $\sqrt{ }$ & \\
\hline & & 2. Membantu siswa yang mengalami kesulitan & & & $\sqrt{ }$ & \\
\hline & & 3. Menganalisis dan menyimpulkan hasil kerja siswa & & & $\sqrt{ }$ & \\
\hline & & 4. Membimbing siswa dalam melaksanakan rencana kegiatan & & & $\sqrt{ }$ & \\
\hline & I & Menganalisis dan mengevaluasi proses pemecahan masalah & & & & \\
\hline & & 1. Membantu siswa memeriksa hasil prosedur pekerjaan siswa & & & $\sqrt{ }$ & \\
\hline & & 2. Membantu menjelaskan masalah / problem yang dihadapi siswa & & & $\sqrt{ }$ & \\
\hline & & 3. Memotivasi siswa yang kurang /belum berpartisipasi aktif & & & $\sqrt{ }$ & \\
\hline & & 4. Menganalisis proses hasil diskusi dan hasil kerja tiap kelompok & & & $\sqrt{ }$ & \\
\hline & & Menutup kegiatan pembelajaran & & & & \\
\hline & & 1. Membimbing siswa menyimpulkan materi & & & $\sqrt{ }$ & \\
\hline & & $\begin{array}{l}\text { 2. Memberikan penekanan pada informasi penting yang perlu } \\
\text { diketahui siswa }\end{array}$ & & & $\sqrt{ }$ & \\
\hline & & 3. Memberikan tugas untuk materi berikutnya & & & & $\sqrt{ }$ \\
\hline & & Jumlah & 0 & 0 & 51 & 12 \\
\hline
\end{tabular}


Keterangan:

Skor 1 = tidak baik

Skor 2 = cukup

Skor 3 = baik

Skor 4 = sangat baik

Kriteria penilaian:

$86 \%-100 \%$ : Kinerja guru sangat tinggi

$76 \%-85 \%$ : Kinerja guru baik

$66 \%-75 \%$ : Kinerja guru cukup

$<65 \%$ : Kinerja guru kurang.

Kriteria penilaian:

Skor maksimal $=80$

Skor hasil pengamatan $=(0+0+51+12)$

$$
=63
$$

Prosentase $=$ Jadi kinerja guru tergolong baik .

Tabel 3

Hasil Obserasi Guru Siklus I

\begin{tabular}{|c|c|c|c|c|c|c|c|}
\hline \multirow[b]{2}{*}{ No } & \multirow{2}{*}{ Aspek Yang Diamati } & \multicolumn{4}{|c|}{ Skor } & \multirow{2}{*}{ Nilai } & \multirow{2}{*}{$\begin{array}{c}\text { Prosentase } \\
(\%)\end{array}$} \\
\hline & & 1 & 2 & 3 & 4 & & \\
\hline 1 & Termotiasi mengikuti pelajaran & & & & $\sqrt{ }$ & 4 & \multirow{6}{*}{$75 \%$} \\
\hline 2 & Memperhatikan penjelasan guru & & & $\sqrt{ }$ & & 3 & \\
\hline 3 & Merespon penjelasan guru & & & $\sqrt{ }$ & & 3 & \\
\hline 4 & Aktif bertanya & & & $\sqrt{ }$ & & 3 & \\
\hline 5 & Menjawab pertanyaan & & & $\sqrt{ }$ & & 2 & \\
\hline 6 & $\begin{array}{l}\text { Kemampuan dalam } \\
\text { mengekspresikan diri }\end{array}$ & & $\sqrt{ }$ & & & 2 & \\
\hline \multicolumn{2}{|c|}{ JUMLAH } & & 2 & 12 & 4 & 18 & $\begin{array}{c}(18 / 24) * 100 \% \\
=75 \%\end{array}$ \\
\hline
\end{tabular}

Keterangan:

Skor 1 = tidak baik

Skor $2=$ cukup

Skor 3 = baik

Skor 4 = sangat baik

Kriteria penilaian:

$86 \%-100 \%$ : Aktivitas siswa sangat baik

$76 \%-85 \%$ : Aktivitas siswa baik

$66 \%-75 \%$ : Aktivitas siswa cukup

$<65 \%$ : Aktivitas siswa kurang. 
Hasil observasi aktivitas guru dan siswa pada siklus I menunujukkan skor $78,75 \%$ dan $75 \%$ artinya bahwa dalam proses pembelajaran siklus I mengalami peningkatan. Maka dikatakan bahwa sebagian besar tingkat aktivitas belajar siswa kelas II SD Negeri Medani 02 Kecamatan Cluwak Kabupaten Pati berada pada kategori tinggi dan cukup. Keberhasilan belajar dapat dilihat pada tabel berikut:

Tabel 4

Deskripsi Kategori Ketuntasan Belajar IPS Siklus 1. ${ }^{15}$

\begin{tabular}{|l|c|c|}
\hline Kategori & Frekuensi & Prosentase \\
\hline Tuntas & 10 & $71,42 \%$ \\
\hline Tidak Tuntas & 2 & $28,58 \%$ \\
\hline Rata-rata & & 76, \\
\hline Total & 12 & $100 \%$ \\
\hline
\end{tabular}

Tabel 4 dapat dilihat bahwa siswa yang tuntas pada siklus ini adalah 10 siswa dengan persentase $71,42 \%$ dan siswa yang belum tuntas pada siklus ini sebanyak 2 siswa dengan persentase $28,58 \%$. Hasil tersebut menunjukkan bahwa pada siklus pertama secara klasikal siswa belum tuntas belajar, karena siswa yang memperoleh nilai $\geq 65$ hanya sebesar 71,42\% lebih kecil dari persentase ketuntasan yang dikehendaki yaitu sebesar $80 \%$. Hal ini disebabkan karena siswa masih merasa baru dan belumterbiasa atau mengerti apa yang dimaksudkan dengan kerja kelompok pada diagram batang 2



Mean atau rata-rata nilai yang diperoleh pada siklus 1 adalah 72,2. Hasil tersebut menunjukkan bahwa pada siklus pertama ini nilai maksimum, minimum, dan rata-rata juga mengalami peningkatan.

\footnotetext{
${ }^{15}$ Dimyati. Belajar dan Pembelajaran. Jakarta: PT. Rineka Cipta, 2009. hlm 101
} 


\section{Refleksi Siklus I}

Pada pelaksanaan pembelajaran siklus I pertemuan 2, guru melakukan penilaian tes unjuk kerja yaitu pengamatan, diskusi kelompok, presentasi dan laporan. Dari hasil penilaian pembelajaran yang dilakukan oleh guru melalui model pembelajaran Picture and

Picture tanpa melihat kecerdasan siswa masih ada siswa yang bermain sendiri dan tidak memperhatikan penjelasan guru. Penerapan model ini sangat baik untuk melatih siswa berani berbicara atau mengeluarkan pendapat baik dalam diskusi maupun menyampaikan presentasi hasil kelompok. Dari hasil observasi dan refleksi pertemuan 2 digunakan untuk perbaikan hasil belajar siklus 2. Hasil pelaksanaan pembelajaran pada siklus I pertemuan 2 diketahui bahwa selama pembelajaran siswa terlihat sudah aktif namun masih ada beberapa kekurangan.

Pelaksanaan refleksi dari siklus 1 tersebut sebagai dasar untuk melaksanakan tindakan pada siklus 2 yang diawali dari perencanaan, pelaksanaan tindakan, observasi dan refleksi. Pelaksanaan pembelajaran siklus 2 merupakan perbaikan pembelajaran siklus I. Pada dasarnya siklus 2 memiliki prinsip kerja yang sama dengan pelaksanaan tindakan siklus pertama yaitu dengan langkah-langkah menyusun RPP, mengajak tim kolaborasi atau guru kelas II sebagai rekan peneliti untuk berkolaborasi dalam penelitian, memadukan hasil penelitian siklus pertama agar siklus kedua lebih efektif, mempersiapkan sumber dan media pembelajaran berupa gambar-gambar, menyiapkan lembar observasi untuk mengamati aktivitas siswa, keterampilan guru dan proses pembelajaran serta menyiapkan alat evaluasi berupa tes tertulis dan lembar kerja siswa.

Pelaksanaan tindakan siklus dua dilaksanakan 2 kali pertemuan, di mana guru melaksanakan pembelajaran sesuai yang sudah direncanakan dalam Rencana Pelaksanaan Pembelajaran. Urutan kegiatan yang dilaksanakan mulai dari kegiatan awal, kegiatan inti dan kegiatan akhir. Adapun skenario pembelajaran juga sama dengan pelaksanaan siklus 1 . Sementara itu kegiatan observasi siklus 2 dilaksanakan dengan mengamati beberapa instrumen pengamatan dan melihat kualitas dan perbaikan dari pelaksanaan siklus 1 . Ketika pembelajaran berlangsung, pengamat menganalisis tingkah laku siswa, di mana siswa berusaha melakukan diskusi sesuai penjelasan guru. Pengamat mengamati, apakah setiap siswa mengerjakan tugas yang diberikan untuk didiskusikan sesuai yang disampaikan guru. 
Tabel 5

Hasil Obserasi Guru Siklus II

\begin{tabular}{|c|c|c|c|c|c|}
\hline \multirow{2}{*}{ Tahap } & \multirow{2}{*}{ Aspek yang diamati } & \multicolumn{4}{|c|}{ Skor penilaian } \\
\hline & & 1 & 2 & 3 & 4 \\
\hline \multirow[t]{7}{*}{ I } & Mengorientasi masalah & & & & \\
\hline & 1.Menjelaskan tujuan pembelajaran & & & & $\sqrt{ }$ \\
\hline & 2.Menyampaikan apersepsi & & & & $\sqrt{ }$ \\
\hline & 3.Menarik perhatian dan minat belajar siswa & & & & $\sqrt{ }$ \\
\hline & $\begin{array}{l}\text { 4.Memunculkan contoh-contoh masalah yang berkaitan dengan } \\
\text { kehidupan sehari-hari }\end{array}$ & & & & $\sqrt{ }$ \\
\hline & $\begin{array}{l}\text { 5.Memotivasi siswa untuk menelaah soal dan menemukan cara } \\
\text { penyelesaiannya sendiri }\end{array}$ & & & & $\sqrt{ }$ \\
\hline & $\begin{array}{l}\text { 6.Mengorganisasikan siswa untuk mengkonstruksi sendiri } \\
\text { pengetahuan yang didapatnya }\end{array}$ & & & & $\sqrt{ }$ \\
\hline \multirow[t]{4}{*}{ II } & $\begin{array}{l}\text { Membimbing kegiatan pembelajaran individual maupun } \\
\text { kelompok }\end{array}$ & & & & \\
\hline & 1. Melakukan pengamatan tiap kelompok & & & & $\sqrt{ }$ \\
\hline & $\begin{array}{l}\text { 2. Mengawasi dan membimbing kegiatan kelompok dengan } \\
\text { instruksi seminimal mungkin }\end{array}$ & & & & $\sqrt{ }$ \\
\hline & 3. Merekam kegiatan siswa & & & & $\sqrt{ }$ \\
\hline \multirow[t]{5}{*}{ III } & Mengembangkan hasil kerja siswa & & & & \\
\hline & $\begin{array}{l}\text { 1.Membimbing siswa dalam mengkonstruksi pengetahuan baru } \\
\text { yang didapat }\end{array}$ & & & & $\sqrt{ }$ \\
\hline & 2.Membantu siswa yang mengalami kesulitan & & & & $\sqrt{ }$ \\
\hline & 3. Menganalisis dan menyimpulkan hasil kerja siswa & & & & $\sqrt{ }$ \\
\hline & 4.Membimbing siswa dalam melaksanakan rencana kegiatan & & & $\sqrt{ }$ & \\
\hline \multirow[t]{10}{*}{ I } & Menganalisis dan mengevaluasi proses pemecahan masalah & & & & \\
\hline & 1.Membantu siswa memeriksa hasil prosedur pekerjaan siswa & & & $\sqrt{ }$ & \\
\hline & 2.Membantu menjelaskan masalah/problem yang dihadapi siswa & & & $\sqrt{ }$ & \\
\hline & 3.Memotiasi siswa yang kurang /belum berpartisipasi aktif & & & $\sqrt{ }$ & \\
\hline & $\begin{array}{l}\text { 4.Menganalisis proses hasil diskusi dan hasil kerja tiap } \\
\text { kelompok }\end{array}$ & & & $\sqrt{ }$ & \\
\hline & Menutup kegiatan pembelajaran & & & & \\
\hline & 1.Membimbing siswa menyimpulkan materi & & & $\sqrt{ }$ & \\
\hline & $\begin{array}{l}\text { 2.Memberikan penekanan pada informasi penting yang perlu } \\
\text { diketahui siswa }\end{array}$ & & & $\sqrt{ }$ & \\
\hline & 3.Memberikan tugas untuk materi berikutnya & & & & $\sqrt{ }$ \\
\hline & Jumlah & 0 & 0 & $\begin{array}{l}2 \\
1\end{array}$ & 52 \\
\hline
\end{tabular}

Keterangan:

Skor 1 = tidak baik

Skor $2=$ cukup

Skor 3 = baik

Skor 4 = sangat baik

Kriteria penilaian: 
$86 \%-100 \%$ : Kinerja guru sangat baik

$76 \%-85 \%$ : Kinerja guru baik

$66 \%-75 \%$ : Kinerja guru cukup

$<65 \%$ : Kinerja guru kurang.

Kriteria penilaian:

Skor maksimal $=80$

Skor hasil pengamatan $=(0+0+21+52)$

$$
=73
$$

Prosentase $=$ Kinerja guru tergolong baik .

Tabel 6

Hasil Observasi Guru Siklus 2

\begin{tabular}{|c|c|c|c|c|c|c|c|}
\hline \multirow{2}{*}{ No } & \multirow{2}{*}{ Aspek Yang Diamati } & \multicolumn{4}{|c|}{ Skor } & \multirow{2}{*}{ Nilai } & \multirow{2}{*}{$\begin{array}{c}\text { Prosentase } \\
(\%)\end{array}$} \\
\hline & & 1 & 2 & 3 & 4 & & \\
\hline 1 & $\begin{array}{l}\text { Termotivasi mengikuti } \\
\text { pelajaran }\end{array}$ & & & & $\sqrt{ }$ & 4 & \multirow{6}{*}{$91,7 \%$} \\
\hline 2 & $\begin{array}{l}\text { Memperhatikan penjelasan } \\
\text { guru }\end{array}$ & & & & $\sqrt{ }$ & 4 & \\
\hline 3 & Merespon penjelasan guru & & & & $\sqrt{ }$ & 4 & \\
\hline 4 & Aktif bertanya & & & & $\sqrt{ }$ & 4 & \\
\hline 5 & Menjawab pertanyaan & & & & $\sqrt{ }$ & 4 & \\
\hline 6 & $\begin{array}{l}\text { Kemampuan dalam } \\
\text { mengekspresikan diri }\end{array}$ & & & $\sqrt{ }$ & & 3 & \\
\hline \multicolumn{2}{|c|}{ JUMLAH } & & & 2 & 20 & 22 & $(22 / 24) * 100 \%=91,7 \%$ \\
\hline
\end{tabular}

Keterangan:

Skor $1=$ tidak baik

Skor $2=$ cukup

Skor 3 = baik

Skor 4 = sangat baik

Kriteria penilaian:

$86 \%-100 \%$ : Aktivitas siswa sangat tinggi

$76 \%-85 \%$ : Aktivitas siswa baik

$66 \%-75 \%$ : Aktivitas siswa cukup

$<65 \%$ : Aktivitas siswa kurang.

Hasil observasi aktivitas guru dan siswa dalam proses pembelajaran siklus 2 pertemuan 2 menunjukkan aktivitas guru mendapat skor $85 \%$ dan aktivitas siswa mendapat skor $91,7 \%$ artinya aktivitas guru dan siswa mengalami kenaikan signifikan dan termasuk dalam kategori sangat baik dan baik. Tabel 6 dapat dilihat bahwa dapat dikatakan bahwa pada siklus 2 mengalami kenaikan yang signifikan.

Tabel 7

Deskriptif Hasil Tes Formatif Siswa Pada Siklus 2

\begin{tabular}{|l|c|c|}
\hline Kategori & Frekuensi & Prosentase \\
\hline Tuntas & 12 & $100 \%$ \\
\hline Tidak Tuntas & 0 & $0 \%$ \\
\hline Rata-rata & & 87,4 \\
\hline jumlah & 12 & $100 \%$ \\
\hline
\end{tabular}


Tabel7 dapat dilihat bahwa siswa yang tuntas pada siklus ini adalah 12 siswa dengan persentase $100 \%$ dan siswa semua tuntas pada siklus ini. Hasil tersebut menunjukkan bahwa pada siklus ke II secara klasikal ketuntasan belajar sudah tercapai sesuai indikator yang telah ditentukan, yaitu $80 \%$ siswa memperoleh nilai $\geq 65$. Untuk memperjelas keterangan tabel 7 dapat dilihat diagram hasil formatif Siklus pada diagram batang 3

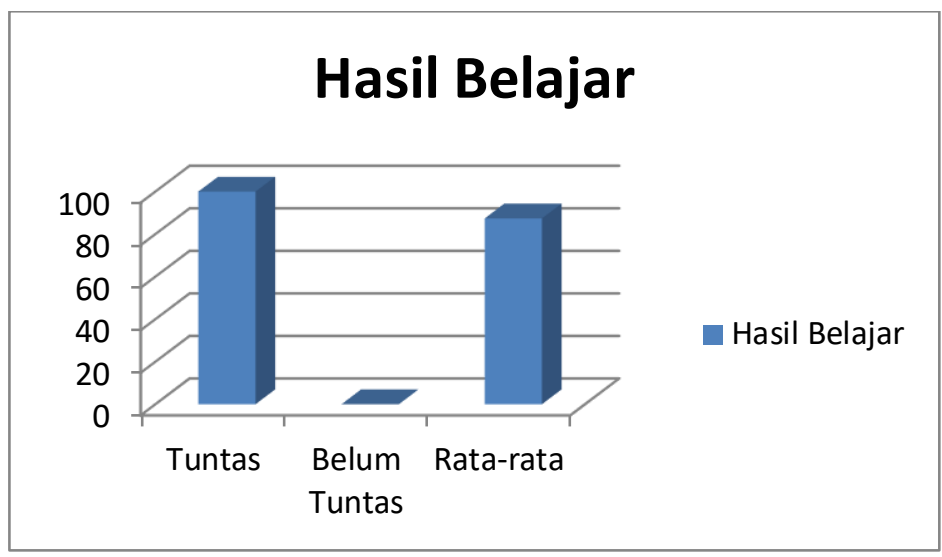

Pada pelaksanaan pembelajaran siklus 2 guru melakukan penilaian tes unjuk kerja yaitu kerja pengamatan, diskusi kelompok, presentasi dan laporan. Dari hasil penilaian pembelajaran yang dilakukan oleh guru melalui model pembelajaran Picture and Picture dengan pembagian kelompok berdasarkan tingkat kecerdasan siswa, semua siswa mengikuti pembelajaran dengan aktif dan siswa berani mengeluarkan pendapat serta menyanggah temannya. Penerapan model pembelajaran Picture and Picture IPS materi dokumen keluarga sebagai sumber belajar pada siswa kelas II SD Negeri Medani pada mata pelajaran IPS 02 Kecamatan Cluwak Kabupaten Pati dapat meningkatkan hasil belajar dan siswa aktif mengikuti pembelajaran. Siswa juga berani mengeluarkan pendapat, baik dalam diskusi maupun dalam presentasi hasil laporan. Pada perbaikan pembelajaran siklus I peneliti menerapkan model pembelajaran Picture and Picture berdasarkan pembagian kelompok tanpa membedakan tingkat kecerdasan siswa, pada akhir siklus I siswa mengalami peningkatan ketuntasan dari prasiklus ketuntasan siswa 42,85\% atau 6 siswa dan pada siklus I ketuntasan siswa 71,42\% atau 10 siswa. Dari uraian di atas peneliti merefleksi sebab-sebab kegagalan dalam perbaikan pembelajaran siklus I, ternyata pada perbaikan pembelajaran siklus I ditemukan bahwa siswa kurang dilibatkan dalam pembelajaran dan guru lebih aktif sendiri dalam pembelajaran.

Pada perbaikan pembelajaran siklus 2 menerapkan model pembelajaran Picture and Picture berdasarkan pembagian kelompok dengan membedakan tingkat kecerdasan dan melibatkan seluruh siswa secara langsung. Pada akhir siklus 2 ketuntasan siswa 
mengalami peningkatan yang signifikan yaitu dari siklus I ketuntasan siswa 71,42\% atau 10 siswa dan pada siklus 2 ketuntasan siswa $100 \%$ atau semua siswa tuntas dengan hasil yang memuaskan, maka peneliti tidak melajutkan siklus berikutnya. ${ }^{16}$ Nilai ratarata yang dicapai siswa pada siklus ini 87,4 bila dibandingkan pada saat kondisi awal yang nilai rata-ratanya 58,57 dan siklus 1 yang hanya 76,92. Pada siklus 2 ini juga terjadi kenaikan nilai rata-rata dari siklus 1 ke siklus 2 adalah sebesar 10,48. Untuk mempermudah membandingkan hasil belajar antara kondisi awal, siklus 1, dan siklus 2 dapat disajikan dalam bentuk tabel sebagai berikut:

Tabel 8

Perbandingan Hasil Belajar IPS Kondisi Awal, Siklus 1, dan Siklus $2{ }^{17}$

\begin{tabular}{|l|l|c|c|c|c|c|c|}
\hline \multirow{2}{*}{ No } & \multirow{2}{*}{ Kategori } & \multicolumn{3}{|c|}{ Jumlah } & \multicolumn{3}{|c|}{ Persentase (\%) } \\
\cline { 3 - 8 } & & $\begin{array}{c}\text { Awdisi } \\
\text { Awal }\end{array}$ & $\begin{array}{c}\text { Siklus } \\
1\end{array}$ & $\begin{array}{c}\text { Siklus } \\
2\end{array}$ & $\begin{array}{c}\text { Kondisi } \\
\text { Awal }\end{array}$ & $\begin{array}{c}\text { Siklus } \\
1\end{array}$ & $\begin{array}{c}\text { Siklus } \\
2\end{array}$ \\
\hline 1. & Tuntas & 7 & 10 & 12 & 42,85 & 76,92 & 100 \\
\hline 2. & Tidak tuntas & 5 & 2 & 0 & 57,15 & 23,08 & 0 \\
\hline 3. & Total & 12 & 12 & 12 & 100 & 100 & 100 \\
\hline 4. & Minimum & 40 & 50 & 70 & & & \\
\hline 5. & Maksimum & 80 & 90 & 100 & & & \\
\hline 6. & Rata-rata & $\begin{array}{c}58,5 \\
7\end{array}$ & 71,42 & 87,4 & & & \\
\hline
\end{tabular}

Tabel 8 diketahui bahwa hasil belajar siswa yang tuntas pada siklus 2 telah mencapai $100 \%$ atau lebih dari indikator kinerja yang diinginkan yaitu lebih dari $80 \%$ siswa yang mendapat nilai $\geq 65$. Hasil belajar pada siklus 2 ini ketuntasan belajar siswa secara klasikal sudah tercapai, dan mencapai indikator kinerja yang diharapkan sehinnga penelitian dihentikan sampai pada siklus 2. Untuk memperjelas keterangan ketuntasan hasil belajar siswa di atas dapat dilihat pada diagram $4 .{ }^{18}$
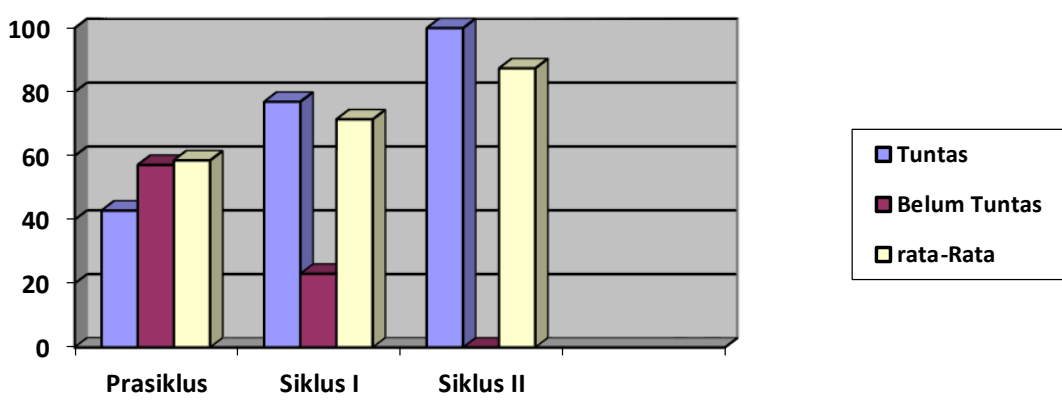

${ }^{16}$ Isjoni, Cooperatie Learning Efektiitas Pemebelajaran kelompok. Bandung: Alfabeta, 2009.

17 Kusnandar, Langkah Mudah Penelitian Tindakan Kelas Sebagai Pengemba ngan Profesi Guru. Jakarta: Rajawali Pers, 2012

18 Komara, Endang. 2009. Gresik. [(http://khoirulanwari.wordpress. com/about/ peran-penelitiantindakan-kelas-ptk-dalam-meningkatkan-profesionalisme-guru/) diunduh pada 14 April 2011] 
Mega Wahyuningsih

\section{Simpulan}

Penerapan model pembelajaran Picture and Picture pada mata pelajaran IPS materi dokumen deluarga sebagai sumber belajar pada siswa kelas II SD Negeri Medani 02 Kecamatan Cluwak Kabupaten Pati dapat meningkatkan hasil belajar dan siswa aktif mengikuti pembelajaran tetapi masih ada beberapa siswa yang bermain serta tidak memperhatikan penjelasan guru. Skor rata-rata kelas yang diperoleh pada akhir siklus I sebesar 71,42. Ketuntasan belajar yang dicapai siswa hanya sebesar 76,92\% atau 10 siswa dan 23,08. Skor tes pada siklus 2 siswa kelas II SD Negeri Medani 02 Kecamatan Cluwak Kabupaten Pati semester 1 tahun 2020/2021 telah menunjukkan persebaran nilai yang masih kurang merata. Hal ini ditunjukkan dengan perbedaan skor tes yang terendah (skor minimal sebesar 65 dan sekor tes tertinggi (skor maksimal) sebesar 100. Kondisi ini menunjukkan terjadinya peningkatan pada hasil belajar siswa. Skor rata-rata kelas yang diperoleh pada siklus 2 sebesar 87,4. Kenaikan dari siklus I ke siklus 2 rata-rata kelas meningkat 15,98 dan tingkat ketuntasan meningkat 23,08\%. Jadi kenaikan hasil belajar siswa dari pra siklus hingga siklus 2 yaitu $57,15 \%$

\section{DAFTAR PUSTAKA}

Anton, M, Aktivitas Belajar, Bandung: Alfabeta, 2001.

Arikunto, Suharsimi, Penelitian Tindakan Kelas, Jakarta: Bumi Aksara, 2008.

Arikunto, Suharsimi, dkk, Penelitian Tindakan Kelas, Jakarta: PT Bumi Aksara, 2010.

Baharudin dan Esa Nur Wahyuni, Teori Belajar dan Pembelajaran, Yogyakarta: ARRUZZ. Media, 2007.

Depdiknas, Kurikulum Tingkat satuan Pendidikan, Jakarta: Depdiknas, 2006.

Diansari, Dewi, Penerapan Model Picture and Picture untuk Meningkatkan Pembelajaran IPA Siswa Kelas I SDN Gampingan 01 Pagak, Skripsi, 2011.

Dimyati, Belajar dan Pembelajaran, Jakarta: PT. Rineka Cipta, 2009.

Djamarah, Syaifyk B, \&Zain, Aswan, Strategi Belajar Mengajar, Jakarta: Rineka Cipta, 2006.

Fisher Alec, Berfikir Kritis- Sebuah Pengantar, Jakarta. Erlangga, 2009.

Gie, Aktiitas Belajar, Jakarta: PT. Rineka Cipta, 2011. 
Isjoni, Cooperatie Learning Efektiitas Pemebelajaran Kelompok. Bandung: Alfabeta. Hakum, 2009.

Kemmis dan Taggrat, Model Penelitian Tindakan Kelas, Jakarta: Bumi Aksara Kurikulum KTSP (Depdiknas, 2006),

Komara, Endang, Gresik, [(http://khoirulanwari.wordpress. com/about/peranpenelitian-tindakan-kelas-ptk-dalam-2011] meningkatkan-profesionalisme-guru/) diunduh pada 14 April, 2009.

Kusnandar, Langkah Mudah Penelitian Tindakan Kelas Sebagai Pengemba ngan Profesi Guru, Jakarta: Rajawali Pers, 2012.

Martanti, Fitria, Penanaman Nilai-nilai Kejujuran Melalui Media Kantin Kejujuran di Pondok Pesantren Al-Hikmah Semarang, Jurnal Sosio Dialektika Volume 2, 2017

Martanti, Fitria, Penanaman Konsep Gender Pada Mata Pelajaran IPS, Jurnal Magistra Volume 8 Nomer 12017.

Thursan, Belajar, Jakarta: Bumi Aksara, 2000. 